\title{
PENGUATAN JEJARING KOMUNITAS MELALUI TINDAKAN KOLABORATIF
} Studi Pada Sepuluh Kampung Iklim di DKI Jakarta

\author{
Anggoro Yudo Mahendro \\ Peneliti dan Pendiri Rumah Sinergi \\ yudomahendro@gmail.com
}

Diterima Redaksi: 06-04-2021 | Selesai Direvisi: 29-05-2021 | Diterbitkan Online 04-06-2021

\begin{abstract}
This research is directed to strengthen the network among the drivers of the Climate Village program in ten RWs in DKI Jakarta. Using collaboration action research, this research uses focus group discussion techniques which are conducted twice in each community. During the FGD twice there was an increase in community network marked by the creation of an organizational structure and work program that had not been made so far. These two outcomes are certainly important for building relationships that are more equal to elements of the local government and also the private sector which tends to impose programs on the community.

Keywords: Social Networking, Focus Group Discussions, Collaborative Action.
\end{abstract}

Abstrak
Penelitian ini ditujukan untuk melakukan penguatan jejaring penggerak program kampung iklim pada 10 RW yang ada di Provinsi DKI Jakarta. Menggunakan penelitian tindakan kolaboratif, penelitiaan ini menggunakan teknik diskusi kelompok terfokus (FGD) yang dilakukan sebanyak dua kali pada masing-masing komunitas. Selama kegiatan dilangsungkan, jejaring komunitas semakin menguat dan meningkat, hal ini ditandai dengan pembuatan struktur organisasi dan juga program kerja yang mereka buat bersama-sama. Dua hasil tersebut menjadi penting untuk membangun relasi yang lebih setara antara komunitas dengan pemerintah dan juga swasta yang ingin terlibat dalam program yang dilaksanakan oleh komunitas.

Kata Kunci : Jejaring Sosial, Diskusi Kelompok Terfokus, Tindakan Kolaboratif

\section{Pendahuluan}

Program Kampung Iklim (Proklim) di DKI Jakarta diharapkan menjadi solusi untuk menangani masalah lingkungan hidup di DKI Jakarta. Pengurangan sampah dari sumber serta pengurangan tingkat polusi udara merupakan dua tujuan utama yang disandarkan kepada kampung-kampung iklim yang tersebar di seluruh Jakarta. Selain melakukan upaya teknis yang terkait dengan adaptasi dan mitigasi perubahan iklim, Dinas Lingkungan Hidup DKI Jakarta juga mendorong upaya penguatan kelembagaan serta dukungan untuk keberlanjutan.

Dalam penelitian sebelumnya Mahendro (2018b), sudah diidentifikasi upaya yang perlu dilakukan untuk menguatkan elemen kelembagaan kampung iklim. Usulan penguatan program kampung iklim diantaranya ialah penguatan pada sisi kebermanfaatan program. Hal ini penting karena kebermanfaatan program kampung iklim selama ini belum dirasakan optimal oleh para warga. Kondisi ini menyebabkan beberapa wilayah yang awalnya sudah memiliki kegiatan 
lingkungan hidup perlahan-lahan meredup. Selain masalah kebermanfaatan program, yang menjadi rekomendasi dalam penelitian sebelumnya ialah terkait dengan dinamika kelompok, yaitu terkait dengan konteks sosial pemukiman, posisi sosial, dan juga peningkatan kapasitas penggiat atau penggerak. Dalam penelitian lain yang juga membahas Prokim Ghina dan Zunariyah (2017) dan Faedlulloh, Irawan \& Prasetyanti (2019) menjelaskan bahwa sisi kelembagaan belum begitu menjadi perhatian serius oleh penggerak. Di sisi lain studi Rifyanti (2018) dan Wahab (2015) sudah mengidentifikasi beberapa hal seperti kepemimpinan dan kesadaran warga dalam untuk terlibat dalam program kampung iklim sebagai salah elemen penting untuk keberlanjutan program.

Oleh karenanya, dalam studi ini akan menggunakan metode penelitian aksi guna mengintervensi jejaring internal yang ada pada masing-masing kampung. Merujuk pada Engestrom (1999) yang telah mengembangkan konsep penelitian aksi kolaboratif yang juga dipadukan dengan pembangunan jejaring yang dikembangkan oleh Plastrik dan Taylor (2004, 2006) penelitian diarahkan untuk menguatkan jejaring internal maupun jejaring eksternal kampung iklim di DKI Jakarta.

\section{Kerangka Konseptual}

Dalam kajian sebelumnya, Mahendro (2018a) menggunakan pendekatan institusional, yaitu mengaitkan komunitas penggerak sebagai institusi informal dengan konteks struktural sabagai institusi formal. Perpaduan dua institusi tersebut, berhasil mendorong pola komunikasi dan pola kerja yang menyesuaikan pada kebutuhan dan kebiasaan masyarakat. Rumusan tersebut terus dikembangkan untuk memperluas jangkauan wilayah. Apalagi pada tahun 2018, RW 07 Pabuaran Tumpeng mendapatkan predikat Kampung Iklim Nasional dari KLHK. Prestasi tersebut semakin menguatkan posisi komunitas dimata pemerintah daerah. Kini melalui lembaga Benua hijau, mereka menyebar anak-anak muda untuk melakukan pendampingan kepada wilayah-wilayah lain yang berminat untuk mengembangan program lingkungan hidup dengan dukungan penuh dari Pemerintah Kota Tangerang.

Menyambung studi tersebut, Mahendro (2018b) menggunakan pendekatan tindakan kolektif untuk melihat dinamika kampung iklim. Dalam kajian tersebut lebih difokuskan untuk melihat relasi antara penggerak dengan komunitas. Posisi sosial menjadi komponen yang penting untuk dimiliki penggerak kampung iklim untuk menguatkan kelembagaan di masingmasing wilayah. Hal ini disebabkan begitu banyak kampung iklim yang keberadaannya tidak berlangsung lama akibat konflik kepentingan antara penggerak dengan pemangku kepentingan ditingkat Rukun Warga (RW). 
Dalam studi kali ini, selain menggunakan dua pendekatan yang sudah dilakukan sebelumnya, juga akan menggunakan pendekatan tindakan kolaboratif yang dikembangkan oleh Plastrik dan Talyor (2006). Tindakan kolaboratif oleh mereka dibagi menjadi tiga jenjang; konektifitas, pesekutuan, dan produktifitas. Tiga jenjang tersebut merupakan tahapan dari yang sederhana menuju hingga ke yang lebih kompleks. Konektifitas ialah tingkat yang sederahana dari tindakan kolektif, yaitu ketika jejaring dapat saling terhubung satu sama lain untuk bisa berbagi informasi. Kemudian, persekutuan ialah pada tingkat medium, yaitu ada proses fasilitasi dari organisasi untuk dapat saling berbagi berdasarkan nilai-nilai serta identitas masing-masing. kemudian, tahap yang paling tinggi ialah produktifitas, dimana organisasi membantu mulai dari tahap perencanaan untuk saling terhubung dengan pihak-pihak yang saling membutuhkan.

Berdasarkan penjelasan di atas, diketahui bahwa tindakan kolaboratif yang ideal ialah pada tahap produktifitas. Dimana ada organisasi yang mengelola sesara professional untuk melakukan perensanaan dan implementasi tindakan kolaboartif. Dalam kajian tersebut, Plastrik dan Taylor (2006) menjelaskan bahwa untuk membentuk nilai diantara anggota dalam jejaring diperlukan beberapa hal; media untuk berkoneksi, pengetahuan, keahlian, dan sumberdaya. Keempat komponten tersebut perlu tersedia dan mudah untuk dapat dibagi dialam jejaring dalam upaya untuk menuju produktiftas.

Dalam kajian sebelumnya, Plarstik dan Taylor (2004) menjelaskan bahwa ada 4 elemen yang perlu dipehatikan dalam upaya membangun kerja kolaboratif. Keempat komponen itu ialah; network origins, network Interaction, network structure, dan network dynamic. Keempat komponen tersebut harus dilaksanakan secara bertahap dan juga dalam pola siklus atau berkesinambungan. Berikut ini ialah penjelasan keempat elemen tersebut.

Berdasarkan konsep Plastrik dan Taylor (2004), diketahui bagaimana sesunggunghnya tindakan kolaboratif harus diarahkan untuk memberikan penjelasan kepada pihak-pihak yang terkait. Dalam tahap asal jejaring, penggerak haruslah membangun argumentasi apa manfaat dari sebuah kegiatan atau program. kemudian, pada tahap interaksi di dalam jejaring yang menjadi aktor utama ialah penggerak. Ia harus memutuskan pihak-pihak mana saja yang akan dilibatkan serta melalui media apa interaksi itu dapat terjalin. Selanjutnya, bagian ketiga ialah diperlukan kesepakatan bersama diantara anggota kelompok untuk menentukan pola koordinasi dan bentuk dari jejaring. Terakhir bagian keempat, ialah proses dimana kelompok harus bersentuhan dengan jejaring eksternal serta konteks sosial, ekonomi, politik, serta budaya yang dinamis. Dengan demikian, diperlukan upaya adaptif dari jejaring agar jejaring dapat berkesinambungan. 
Pendekatan tindakan kolaboratif sesungguhnya lebih popular untuk digunakan dalam konteks pembelajaran baik dalam kelas maupun di luar kelas yang dikenal dengan penelitian tindakan kolaboratif atau penelitian tindakan kelas. Dalam kajian yang dikembangkan oleh Engestrom (1999) terkait dengan aktifitas di dalam sistem menjadi rujukan utama dalam aliran ini. Ada enam elemen pokok yang saling tergubung satu sama lain yaitu; subyek, objek, pembagian kerja, aturan main (rules), media (tools), dan komunitas. Skema ini sesungguhnya merupakan upaya yang disusun agar subjek melaksanakan objek yang tak lain merupakan sebuah misi yang disusun untuk meningkatkan kapasitas dari si subjek. Dalam proses tersebut, maka perlu diperhatikan dan disiapkan infrastruktunya seperti media, aturan main, dan pembagian kerja. Proses yang berjalan diharapkan akan menghasilkan perubahan yang signifikan bagi si subjek, yang pada gilirannya akan memicu komunitas untuk terlibat didalam jejaring yang sudah terbentuk.

Dalam skema tindakan kolaboratif sebagaimana gambar 1 perlu digarisbawahi bahwa interaksi antar elemen yang ada diarahkan untuk mengikuti objek yang sudah ditetapkan. Kemudian interaksi antar elemen ini dilihat sebagai sebuah eksperimentasi yang perlu diamati sesara simultan dan diamati hasilnya. Tindakan kolaboratif sesungguhnya diarahkan untuk terus menerus dilakukan atau merupakan sebuah siklus yang terus berjalan sebagaimana yang dijelaskan oleh Plastrik dan Taylor (2004). Hal ini tentunya juga sejalan dengan konsep tindakan kolektif yang sebelumnya sudah dikaji dalam Mahendro (2018b).

\section{Gambar 1}

\section{Skema Tindakan Kolaboratif Engestrom}

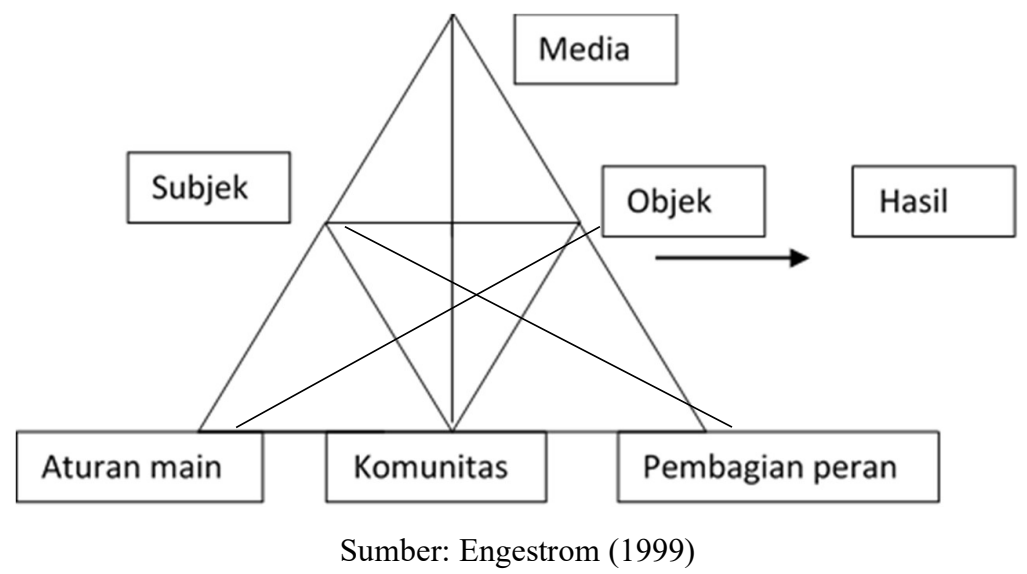

Berdasarkan diskusi di atas dengan demikian dapat disimpulkan bahwa tindakan kolaboratif merupakan; 1) sebuah proses yang didisain dengan baik oleh sekelompok orang yang bertugas untuk menjadi pemicu sekaligus mengamati proses kolaborasi tersebut; 2) 
diperlukan perangkat lunak dan perangkat keras untuk mendukung proses kerja kolaboratif tersebut yang juga sudah harus disiapkan sebagai elemen pendukung (media, aturan main, dan pembagian kerja); 3) tindakan kolaboratif merupakan proses yang tidak pernah selesai, ia merupakan siklus yang harus terus bergulir, berubah dan beradaptasi untuk menjaga agar sistem tetap berjalan.

\section{Metodologi Penelitian}

Dengan demikian, maka yang digunakan ialah penelitian aksi kolaboratif (collaborative action research). Skema yang dilakukan sebagaimana yang terdapat dalam gambar 3. Peneliti akan menyiapkan prasarat yang dibutuhkan seperti pembagian tugas, aturan, dan juga media. Selain itu, penting juga untuk disampaikan bahwa menurut Koshy (2005), penelitian aksi, termasuk penelitian ini, sesungguhnya merupakan proses siklus yang harus diamati dan dicatat dari setiap tindakan yang dilakukan. Hasil pengamatan tersebut kemudian dianalisa kembali sebagai bahan perencanaan untuk penelitian selanjutnya.

Proses ini dilakukan selama dua kali pertemuan yang melibatkan semua pihak yang terkait dengan program kampung iklim. Pertemuan pertama ialah melakukan identifikasi kendala dan potensi yang dimiliki masing-masing kampung iklim. Kemudian pada pertemuan yang kedua ialah membahas mengenai rencana kerja kampung iklim yang disepakati bersama oleh peserta FGD. Dengan demikian, sesungguhnya yang menjadi subjek (dalam skema gambar 1) dalam penelitian ini ialah para peserta FGD. Penelitian ini dilaksanakan oleh tim, satu orang koordinator dan lima orang anggota. Koordinator bertanggungjawab untuk memastikan proses penelitian berjalan sesuai dengan perencanaan serta melakukan proses penguatan jejaring eksternal. Lima orang anggota tim masing-masing fokus melakukan proses penguatan jejaring internal di dua kampung. Dalam penelitan ini ada 10 (sepuluh) kampung iklim yang dijadikan lokasi penelitian.

Penelitian ini dilakukan selama dua bulan, yaitu dari bulan akhir Juli hingga awal September 2019. Setiap kegiatan dilaksanakan dengan mempertimbangkan waktu luang para anggota kelompok kampung iklim. Sebelum kegiatan FGD dilangsungkan, peneliti melakukan pemetaan awal dengan mengunjungi lokasi Kampung Iklim sekaligus untuk menyepakati waktu dengan para penggerak. Selain itu, juga dilakukan pengamatan dan wawancara informal dengan beberapa pihak untuk mendapatkan informasi yang tidak terwadahi melalui FGD. Terkait dengan tempat, kegiatan penguatan jejaring internal dilakukan pada masing-masing lokasi kampung iklim yang memungkinkan, seperti aula Rukun Warga (RW). 


\section{Kondisi Pemukiman}

10 lokasi kampung iklim memiliki konteks pemukiman yang berbeda satu sama lain. Merujuk pada tabel dibawah ini, ada tiga lokasi yang merupakan wilayah pemukiman padat penduduk, ada tiga lokasi yang merupakan komplek sederhana, satu kompleks elit, dan dua wilayah merupakan pemukiman campuran. Kondisi pemukiman ini tentunya juga berkaitan dengan ruang dan fasilitas publik yang ada. Pemukiman padat misalnya, dapat dipastikan sangat minim dengan ruang dan fasilitas publik, sedangkan kompleks sederhana dan yang di atasnya dapat dipastikan masih memiliki ruang publik yang memadai.

Ialah Kampung Iklim Pangadegan, Rawasari, dan Kebon Pala yang masuk kedalam kategori pemukiman padat. Pemukiman tersebut sesungguhnya berada di lokasi yang sangat strategis, kampung mereka terhimpit dengan pusat ekonomi dan pemerintahan. Akses masuk ke rumah mereka hanyalah gang sempit yang maksimal dilalui oleh dua orang. Dalam rangka melangsungkan kegiatan, biasanya mereka memanfaatkan lokasi got yang sudah ditutup dengan beton. Ruang yang sempit itu mereka gunakan untuk melakukan kegiatan penghijauan seperti dengan pot dan juga hidroponik. Bahkan di Pangadegan, bagian atas got selain digunakan untuk meletakan rak hidroponik juga digunakan untuk membuat kolam ikan lele permanen yang dibagun dengan menggunakan semen. Selain kesulitan untuk melaksanakan program lingkungan, untuk lokasi kegiatan berkumpul bersama juga sulit, sehingga yang kerap menjadi lokasi berkumpul ialah tempat ibadah seperti mushola dan masjid.

Kampung Iklim Rorotan, Cempaka Putih Timur, Lenteng Agung, dan Ciracas karena merupakan kompleks yang tertata, di sana terdapat ruang publik yang dapat digunakan untuk kegiatan masyarakat, termasuk kegiatan Proklim. Rorotan memiliki lahan sendiri yang sangat luas. Lahan tersebut merupakan fasilitas umum dari kompleks Green Garden. Meskipun saat ini masih ada permasalahan legalitas tetapi sebagian besar kegiatan proklim dilaksanakan di lokasi tersebut. Kemudian, Cempaka Putih Timur memanfaatkan lahan ditepi kali untuk kegiatan proklim. Lahan yang panjang itu, digunakan untuk melektakan rak-rak hidroponik sekaligus menjadi lokasi berkumpul bersama. Selain lokasi tersebut, gang-gang disetiap RT sebagian besar sudah dilakukan penghijauan dengan berbagai jenis tanaman termasuk tanaman buah anggur yang sudah beberapa kali dipanen. Sedangkan di Lenteng Agung karena merupakan perumahan dinas bagi pekerja di Dinas LH, ada banyak fasilitas umum yang bisa digunakan sebagai tempat untuk bank sampah dan juga pengelolaan sampah organik. Selain itu, warga juga memanfaatkan tepian sungai Ciliwung yang masih sangat asri untuk ditanami dengan tanaman keras. RW 03 Ciracas sebagian wilayahnya merupakan rumah dinas kepolisian yang berbatasan langsung dengan pemukiman padat. Kampung iklim ini juga diapit 
oleh beberapa pabrik sehingga dikelilingi tembok besar yang membatasi wilayah pemukiman dan kawasan industrial. Batas tersebut masih ada sisa lahan yang kemudian ditanami oleh ibuibu PKK dengan tanaman herbal, seperti jahe, lengkuas, kunyit dan lain sebagainya.

Di sisi lain, Sunter Jaya dan Duri Kosambi meskipun merupakan perkampungan namun secara visual sudah tertata sebagaimana kompleks perumahan. Bedanya mereka tidak memiliki ruang publik yang dimiliki bersama, namun rumah-rumah mereka memiliki pekaranagan yang cukup. Keduanya sama-sama merupakan perkampungan betawi yang memiliki kesamaan kultur sehingga tetap guyub. Disebabkan tidak adanya fasilitas umum, kegiatan proklim di dua wilayah ini rentan tergusur. Seperti halnya di wilayah Duri Kosambi, pusat kegiatan yang dahulu mereka gunakan kini sudah tidak ada lagi, "kita sudah pindah dua kali, dulu ini tempat kita, sekarang sudah dibangun menara masjid" tutur salah seorang penggiat. Begitu pula di Sunter Jaya, lahan yang digunakan untuk bergiat merupakan tanah pribadi milik ketua RW saat ini, kedepan jika lahan itu digunakan maka mereka harus mencari lokasi yang baru.

\section{Tabel 1}

Konteks Sosial Kampung Iklim

\begin{tabular}{|c|c|c|c|c|}
\hline Lokasi & $\begin{array}{l}\text { Kategori } \\
\text { Pemukiman }\end{array}$ & $\begin{array}{l}\text { Program } \\
\text { Unggulan }\end{array}$ & $\begin{array}{l}\text { Penggerak } \\
\text { utama }\end{array}$ & $\begin{array}{l}\text { Soliditas } \\
\text { Penggerak }\end{array}$ \\
\hline Rorotan RW 01 & Kompleks sederhana & Taman Hijau & KWT & Minim \\
\hline $\begin{array}{l}\text { Sunter Jaya RW } \\
09\end{array}$ & Kompleks sederhana & Produksi Pangan & PKK & Sedang \\
\hline Rawasari RW 02 & Pemukiman padat & Gang Hijau & $\begin{array}{l}\text { PKK dan } \\
\text { Ketua RT }\end{array}$ & Baik \\
\hline $\begin{array}{ll}\text { Cempaka } & \text { Putih } \\
\text { Timur RW } 03\end{array}$ & $\begin{array}{l}\text { Kompleks elit dan } \\
\text { pemukiman padat }\end{array}$ & Gang Hijau & $\begin{array}{l}\text { Poktan dan } \\
\text { ketua RT }\end{array}$ & Baik \\
\hline $\begin{array}{l}\text { Kebon Pala RW } \\
09\end{array}$ & Pemukiman padat & $\begin{array}{l}\text { Penghijauan } \\
\text { Lidah Buaya }\end{array}$ & $\begin{array}{l}\text { KWT dan } \\
\text { ketua RT }\end{array}$ & Sedang \\
\hline Ciracas RW 03 & $\begin{array}{l}\text { Pemukiman Padat } \\
\text { dan kompleks } \\
\text { sederhana }\end{array}$ & Taman Toga & Pengurus RW & Baik \\
\hline $\begin{array}{l}\text { Lenteng Agung } \\
\text { RW 09 }\end{array}$ & $\begin{array}{l}\text { Kompleks } \\
\text { sederhana/ rumah } \\
\text { dinas }\end{array}$ & $\begin{array}{l}\text { Pengelolaan } \\
\text { Sampah }\end{array}$ & PKK & Sedang \\
\hline $\begin{array}{l}\text { Pengadegan RW } \\
01\end{array}$ & Pemukiman padat & Hidroponik & Ketua RT & Minim \\
\hline
\end{tabular}




\begin{tabular}{|l|l|l|l|l|}
\hline $\begin{array}{l}\text { Duri Kosambi } \\
\text { RW 03 }\end{array}$ & Kompleks sederhana & $\begin{array}{l}\text { Komposting dan } \\
\text { Bank Sampah }\end{array}$ & Ketua RT & Baik \\
\hline $\begin{array}{l}\text { Meruya Utara } \\
\text { RW 06 }\end{array}$ & Kompleks elit & Taman Hijau & Pengurus RW & Sedang \\
\hline
\end{tabular}

Sumber: Diolah dari data Penelitian tahun 2019

Satu-satunya Kampung Iklim yang berlokasi di pemukiman elit atau mewah ialah Meruya Utara. Pusat kegiatan kampung iklim terletak di taman kompleks yang merupakan fasilitas umum yang diperuntukan bagi warga oleh pengembang. Taman yang luas ini berdampingan dengan lapangan sehingga situasinya selalu ramai di saat akhir pekan saat warga kompleks libur. Akhir pekan merupakan waktu yang digunakan bagi penggerak Proklim untuk melaksanakan kegiatan seperti pertanian perkotaan, budidaya ikan, dan juga kini sedang dikembangkan penerapan biogas yang juga dilakukan di taman tersebut.

\section{Dinamika Kegiatan Kampung Iklim}

Berdasarkan data di atas, diketahui bahwa kegiatan yang lebih banyak dilaksanakan oleh penggerak proklim ialah terkait dengan penghijauan dan pertanian perkotaan. Khusus untuk di wilayah Kebon Pala RW 09 tanaman yang dikembangkan ialah lidah buaya. Lidah buaya dibudidayakan secara massif oleh warga, karena sudah dikelola untuk dijadikan produk herbal yang memiliki nilai ekonomi. Proses pengolahan dan produksi juga dilakukan oleh warga setempat, sehingga kegiatan budidaya lidah buaya berjalan berkesinambungan hingga saat ini.

Kegiatan hidroponik yang dilaksanakan di Cempaka Putih Timur juga sudah meningkat menjadi aktivitas ekonomi. Sayuran dari hasil hidroponik sudah memiliki pelanggan, meskipun masih skala rumah tangga. Diketahui bahwa sayuran dari hasil hidroponik memiliki keunggulan dari sisi kandungan gizi serta terjamin organik. Sesungguhnya permintaan terhadap hasil produksi terus datang, namun karena adanya keterbatasan lahan serta sarana dan prasarana penunjang maka saat ini produksi belum bisa ditingkatkan. Kondisi berbeda dialami oleh Pangadegan, meski dikenal sebagai kampung hidroponik namun kegiatan belum bisa kontinyu diakibatkan kendala kelembagaan yang belum terkonsolidasikan dengan baik antar kelompok penggerak.

Sedangkan wilayah seperti Meruya Utara dan Rorotan kegiatan pertanian perkotaan dilaksanakan di fasilitas umum mereka. Tanaman obat dan keluarga (toga) dan juga hidroponik ditempatkan di lokasi ini. Kedua tempat ini terus dikembangkan dengan berbagai kegiatan seperti budidaya lele, dan juga pembuatan kompos. Bahkan di Meruya Utara dibuat 
pemanfaatan biogas namun belum digunakan oleh rumah tangga, hanya percontohan saja. Taman di Rorotan sudah dikelola secara intensif oleh KWT (kelompok wanita tani) di sisi lain Meruya Utara hanya dikelola saat waktu libur diakhir pekan.

Di sisi lain, kegiatan pertanian perkotaan tidak begitu semarak di Sunter Jaya, namun mereka lebih dikenal sebagai penghasil produk tanaman herbal seperti bir pletok dan minuman wornas (wortel dan nanas). Upaya menanam tanaman bahan baku seperti jahe sudah pernah dicoba, namun sampai saat ini belum membuahkan hasil. "Dulu kita pernah dapat bibit jahe dan kita tanam, tetapi karena lupa disiram nga ada yang urus ya pada mati' ujar ketua PKK. Alhasil mereka lebih memilih membeli bahan baku dibanding harus menanam terlebih dahulu.

Kegiatan pengelolaan sampah saat ini sedang digalakan oleh pemerintah Provinsi DKI Jakarta. Dinas Lingkungan Hidup dan TP PKK DKI Jakarta meluncurkan program SAMTAMA yang merupakan kepanjangan dari sampah tanggung jawab bersama. Ada $22 \mathrm{RW}$ yang menjadi percontohan termasuk beberapa lokasi dari 10 kampung iklim yang dikaji yaitu Rorotan, Cempaka Putih Timur, dan Rawasari. Bank sampah merupakan salah satu kegiatan yang dilakukan untuk pengurangan sampah, bahkan khusus kegiatan ini sudah ada instruksi gubernur agar diimplementasikan di setiap RW dan unit pendidikan. Dengan konteks demikian, dapat dipahami sesungguhnya dukungan struktural atas penanganan sampah sangat tinggi. Namun, kenyataannya hampir semua lokasi yang dikaji belum menunjukan ada pola yang baik dalam pengelolaan sampah.

Hanya ada satu kampung yang terpadu melaksanakan program tersebut yaitu Lenteng Agung RW 09, hal ini dipahami karena wilayah tersebut merupakan rumah dinas pekerja di Dinas LH DKI Jakarta, bahkan mereka menempatkan petugas khusus untuk mengurusi bank sampah dan juga pengelolaan sampah organik. Duri Kosambi RW 03 sesungguhnya memiliki sejarah panjang dalam pengelolaan sampah, baik organik mapun anorganik. Kegiatan tersebut dilakukan secara kolektif yang dimotori oleh beberapa ketua RT, namun karena lahan yang digunakan kini sudah diubah fungsi menjadi bangunan mereka tidak lagi bergiat untuk menjalankan program.

Di sisi lain, program lainnya yang terkait dengan proklim seperti lubang biopori, sumur resapan, pengelolaan air limbah dan penampungan air hujan tidak begitu menjadi perhatian. Hal ini dipahami karena kegiatan tersebut tidak membutuhkan intensitas perawatan yang rutin. Selain itu, program ini tidak dilakukan secara massif dan juga tidak memiliki dampak langsung terhadap masyarakat. Kondisi ini berbeda di kampung iklim Lenteng Agung yang merupakan rumah dinas dari pegawai Dinas Lingkungan Hidup merupakan wilayah yang memiliki semua program ini dan dipantau secara berkala. Elemen-elemen tersebut merupakan 
program yang dirancang oleh ketua rumah dinas, dengan demikian ada kekuatan struktural yang menyebabkan program ini bisa terus berjalan.

\section{Dinamika Penggerak Kampung Iklim}

Sesungguhnya program kampung iklim merupakan keberlanjutan dari kegiatan lingkungan yang dilaksanakan sebelumnya. Dalam penelitian sebelumnya Mahendro (2018b) sudah dijelaskan bahwa ada beberapa kegiatan yang siginfikan menjadi embrio dari kampung iklim. Begitupun dari sisi penggerak, sudah ada beberapa kelompok seperti FORMAPEL (forum masyarakat peduli lingkungan) yang dibentuk sudah cukup lama. Dari sisi kapasitas dalam teknik lingkungan maupun dari sisi organisasi mereka cukup mumpuni. Diketahui ada beberapa penggiat kawakan yang memiliki peran signifikan untuk mengerakan kampung iklim di wilayahnya sendiri, setidaknya ada tiga wilayah yaitu Ciracas, Cempaka Putih Timur, dan Duri Kosambi. Dengan keterlibatan mereka maka kegiatan di kampung iklim tersebut berjalan berkesinambungan, kecuali di Duri Kosambi karena adanya permasalahan yang pelik dengan UKPD terkait.

Selain itu, yang tidak kalah penting ialah kapasitas mereka dalam membangun sisi kelembagaan dari kampung iklim. Salah satu hal yang bisa dirasakan ialah kekompakan warga yang terbangun dalam melaksanakan program lingkungan hidup termasuk proklim (lihat tabel 1). Kemudian, yang tidak kalah penting adalah adanya desiminasi pengetahuan di kalangan penggerak. Diketahui ditiga kampung iklim tersebut ada banyak warga yang memiliki kapasitas teknis dalam penghijauan, pengelolaan sampah, dan lain sebagainya. Sehingga pada sisi penggerak utama yang menjadi pendorong utama kegiatan ialah ketua-ketua RT dan pengurus RW.

Sedangkan untuk kampung yang lain, yang tidak memiliki 'tokoh' tentu agak kesulitan untuk menjaga konsistensi. Maka tumpuan mereka ialah PKK untuk menjadi motor penggerak kegiatan lingkungan hidup termasuk program kampung iklim. Tanpa mengurangi peran dari PPK, mesti diakui selama ini PKK belum memiliki pola kerja organisasi yang mapan dari sisi kelembagaan. Program PKK masih terpaku pada kegiatan, belum pada tingkat mengorganisir. Alhasil kegiatan yang dilangsungkan akan lebih berorientasi pada kesemarakan kegiatan dibandingkan dengan keberlanjutan program. Hal ini perlu dipahami karena kegiatan yang dilaksanakan oleh PKK begitu banyak dan sangat beragam sektor, olehkarenanya mereka agak kesulitan untuk fokus pada satu program. Kondisi ini terlihat dari Kampung Sunter Jaya, Rawasari, dan Lenteng Agung.

Kemudian yang juga menarik ialah kasus pada kampung iklim di Kebon Pala, Rototan, 
dan Pangadegan. Ketiga kampung ini tidak digerakan oleh PKK, tetapi oleh Kelompok Tani dan KWT (kelompok wanita tani) yang dibentuk oleh dinas atau sudin KPKP untuk mewadahi kegiatan pertanian dan pengembangan ketahanan pangan. Sebelumnya mereka mengikuti serangkaian pelatihan dari instansi tersebut dan kemudian mengembangkan kegiatan tersebut. Kapasitas teknis mereka cukup mumpuni namun dari sisi pengembangan masyarakat sangatlah minim. Dengan demikian, ada kesan yang terbangun kegiatan yang mereka lakukan sangatlah ekslusif dan tidak memberi ruang untuk elemen masyarakat lain untuk berpartisipasi. "dari dulu saya mau gabung, tetapi kok susah ya, kegiatan yang tau ya kelompok mereka sendiri” kata ketua PKK Rorotan.

Situsasi agak berbeda di Meruya Utara, hal ini dipahami karena konteks pemukiman kompleks elit tempat mereka tinggal. 10 RT dari RW 06 Meruya Utara berdada di dalam komplek elit Green Garden, sehingga pola interaksi mereka sangatlah kurang. Begitu juga dari sisi kelompok masyarakat yang ada, hampir tidak ada organisasi ketetanggan yang lain selain kepengurusan RW dan RT pada pemukiman tersebut. Kekurangan itu mereka tutupi dengan keterbukaan terhadap pihak-pihak yang mau berpartisipasi untuk mengembangkan kegiatan lingkungan di taman yang mereka miliki.

\section{Keterlibatan Pengurus RW}

Kampung iklim di DKI Jakarta diarahkan setingkat RW, meskipun dalam aturan sesungguhnya dapat pula setingkat kelurahan. Hal ini dipahami karena wilayah RW lebih sempit sehingga mudah di kelola dan juga sebagian besar RW di Jakarta juga sudah memiliki berbagai kegiatan mandiri dengan berbagai macam corak dan elemen yang bergiat didalamnya. Pelibatan ketua dan pengurus RW dalam kegiatan kampung iklim sangatlah penting, karena selain terkait dengan administrasi juga terkait dengan legitimasi. Sebagaiman diketahui ketua RW dipilih melalui proses demokratis menjadikan sosoknya tokoh formal sekaligus informal.

Dengan demikian, dapat diketahui bahwa ketua dan pengurus RW memiliki tanggungjawab yang sangat besar baik yang terkait dengan permasalahan formal dan informal. Termasuk juga dengan berbagai program pemerintah, idealnya pengurus RW harus hadir untuk memberikan dukungan penuh dalam rangka upaya memajukan warga yang dipimpinnya. Meskipun demikian, tentunya tidak semua RW memiliki waktu, kapasitas, dan kemauan untuk mendukung kegiatan pemerintah, seperti program kampung iklim. Dari 10 wilayah yang dikaji ada tiga tipologi ketua RW dalam merespon proklim. Sebagaimana tabel di bawah ini. 


\section{Tabel 2}

Pola Keterlibatan Ketua RW dalam Kampung Iklim

\begin{tabular}{|l|l|}
\hline Kondisi & Lokasi \\
\hline Ketua RW mendukung dan terlibat & $\begin{array}{l}\text { Sunter Jaya, Rawasari, Cempaka Putih Timur, } \\
\text { Lenteng Agung, Duri Kosambi, dan Meruya Utara }\end{array}$ \\
\hline Ketua RW mendukung tetapi tidak terlibat & Ciracas \\
\hline Ketua RW tidak mendukung & Rorotan, Pangadegan, Kebon Pala \\
\hline
\end{tabular}

Sumber: diolah dari data penelitian

Pertama, ialah ketua RW yang langsung terlibat aktif mendorong program. Jumlah kampung iklim yang dikaji cukup banyak yang memiliki tipologi ini seperti; Sunter Jaya, Rawasari, Cempaka Putih Timur, Lenteng Agung, Duri Kosambi, dan Meruya Utara. Dengan demikian, sesungguhnya posisi penggerak kampung iklim memiliki kekuatan legitimasi yang besar. Kegiatan kampung iklim juga akan lebih merata, karena kegiatan yang dilaksanakan tentunya akan disosialisasikan kepada RT-RT yang berada dibawah nanungannya. Meskipun demikian, keaktifan ketua RW tidak serta merta membuat kegiatan berjalan secara masif. Hal ini terkait juga dengan kapasitas dan kemauan sosok tersebut untuk mendorong program berjalan. Situasi ini terlihat pada Kampung Iklim Sunter Jaya dan Rawasari disebabkan hanya bertumpu kepada PKK RW untuk menjalankan program, sehingga kegiatan program kampung iklim belum semarak. Kemudian Meruya Utara karena terkait dengan konteks sosiologis pemukiman elit, sehingga ketua RW sulit untuk melibatkan partisipasi ketua RT maupun elemen warga yang lainnya. Tiga kampung yang lain bisa merata karena adanya soliditas dikalangan ketua RT, baik karena faktor kultural sebagaimana Cempaka Putih Timur dan Duri Kosambi, maupun faktor struktural seperti kampung iklim Lenteng Agung.

Kedua, ketua RW mendukung namun tidak terlibat secara aktif. Kondisi seperti ini terlihat pada Kampung Iklim Ciracas. Kondisi ini dipahami karena adanya kesibukan ketua RW yang merupakan anggota kepolisian, sehingga ia tidak bisa terlibat secara aktif karena kesibukan dalam pekerjaan. Meskipun demikian, Kampung Iklim Ciracas melalui pengurus RW yang lain dan ketua-ketua RT memiliki komitmen yang tinggi untuk mengembangkan program lingkungan hidup termasuk kampung iklim. selain itu, elemen-elemen lain juga terlibat aktif tetap dalam koordinasi RW.

Kategori ketiga ialah ketua RW tidak mendukung kegiatan. Dalam kategori ini yang dimaksud ialah ketua RW cenderung enggan atau tidak mau tau dengan kegiatan kampung iklim. Ada beberapa faktor yang menyebabkan konsisi ini terjadi, pertama ialah terkait dengan 
ketidaktahuan akan program dan juga yang kedua ialah karena faktor ketidaksukaan terhadap penggiat kampung iklim. Tiga kampung iklim yang dalam kategori ini ialah Rorotan, Kebon Pala, dan Panadegan. Kampung Iklim Rorotan, Pangadegan, Kebon Pala memiliki permasalahan yang relatif sama, yaitu penggiat kampung iklim berjalan tanpa ada koordinasi yang baik dengan ketua maupun pengurus RW. Dengan situasi demikian, maka ketua RW memilih untuk enggan terlibat lebih jauh dalam program kampung iklim. Dengan situasi seperti ini, maka peneliti mendorong agar Ketua RW terlibat dalam FGD agar mengetahui secara detail tentang kampung iklim. Selain itu, FGD juga merupakan momentum agar para penggerak kampung iklim dapat berinteraksi secara terbuka dengan elemen warga yang lain, sehingga di masa datang kegiatan kampung iklim dapat berjalan secara berkesinambungan.

\section{FGD Pertama: Pemetaan Potensi dan Masalah}

Sebagaimana diketahui bahwa penelitian ini menggunakan pendekatan aksi dengan merujuk pada konsep tindakan kolaboratif. Dalam skema tersebut, FGD merupakan salah satu media bagi komunitas untuk bisa merumuskan kembali aturan main, pembagian peran, dan kepentingan bersama (komunitas) dalam rangka menuju tujuan (objek). FGD dilaksanakan selama dua kali selang waktu kurang lebih selama satu minggu. Dalam FGD ini selalu dipandu oleh peneliti yang sama untuk menjaga konsistensi dari hasil yang disepakati. Peserta FGD merupakan kelompok penggerak yang selama ini aktif bergiat dalam kegiatan lingkungan hidup.

Dinamika FGD tentunya berbeda-beda antara satu kampung dengan kampung yang lain. Menariknya, hampir semua wilayah antusias untuk melaksanakan kegiatan ini. Hal ini menunjukan adanya komitmen yang tinggi dari warga untuk mengembangkan kegiatan. Dalam FGD ini para peserta dipancing untuk aktif untuk berkomentar terkait kegiatan yang mereka lakukan. Berikut ini ialah gambaran singkat mengenai hasil diskusi pertama.

\section{Tabel 3}

\section{Identifikasi Potensi dan Masalah Kampung Iklim}

\begin{tabular}{|l|l|}
\hline Potensi & Masalah \\
\hline Kapasitas SDM & Lahan \\
\hline Jejaring & Sarana Prasarana \\
\hline Lahan & Pembinaan \\
\hline Komitmen Warga & Komitmen Warga \\
\hline
\end{tabular}

Sumber: Diolah dari data penelitian

Berdasarkan informasi di atas, diketahui bahwa ada beberapa poin yang muncul pada 
kolom yang berbeda. Poin pertama ialah lahan, sebagaimana diketahui dari penjelasan sebelumnya bahwa ada perbedaan yang konteks pemukiman yang menyebabkan perbedaan ini. Tentunya bagi mereka yang berlokasi dipemukiman padat memandang bahwa keterbatasan lahan merupakan masalah, di sisi lain bagi yang tinggal di kompleks sederhana dan kompleks elit memandang keterbatasan lahan merupakan potensi. Kemudian pada poin komitmen warga, bagi kampung yang memiliki soliditas warga tentunya memandang bahwa hal tersebut merupakan potensi, demikian pula sebaliknya.

Kapasitas SDM sebagian besar mucul sebagai potensi dari kampung iklim. Hal ini dipahami karena kampung iklim yang dikaji merupakan tingkat lanjut. Semua kampung iklim ini sudah banyak berinteraksi dengan para ahli baik dari kalangan akademisi maupun praktisi yang dijembatani oleh pihak pemerintah. Selain itu, saat ini informasi mengenai teknik lingkungan yang aplikatif sudah banyak bisa dijumpai melalui media sosial, baik yang secara teks maupun audio visual.

Kemudian yang dianggap sebagai potensi berikutnya ialah jejaring, dalam hal ini ialah jejaring eksternal. Sebagaimana diketahui sebagai ibu kota negara, Jakarta merupakan pusat pemerintahan sekaligus pusat bisnis. Dengan dinamika tersebut, sangat wajar para penggiat kampung iklim yang selama ini menjalankan kegiatan lingkungan hidup bersentuhan langsung dengan pemerintah pusat maupun pemprov DKI Jakarta, kalangan dunia usaha, perguruan tinggi dan juga penggiat masyarakat sipil. Bahkan beberapa kampung iklim sudah melakukan kerja sama yang intensif lengkap dengan semua elemen yang disebutkan sebelumnya.

Foto. 1

Kegiatan FGD Pertama di Aula RW 03 Cempaka Putih Timur

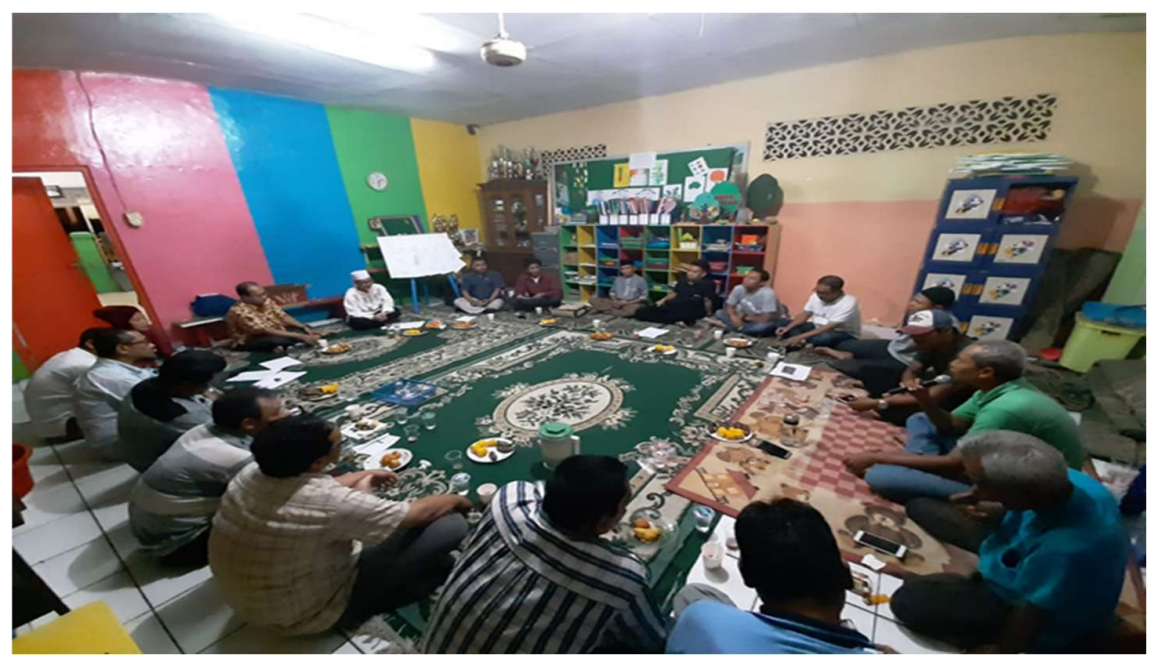

Sumber: Dokumentasi Tim Peneliti 
Pada sisi kendala ada dua hal lagi yang mengemuka yaitu terkait dengan sarana dan prasarana serta pembinaan. Terkait dengan sarana dan prasarana, dapat diketahui bahwa untuk kegiatan lingkungan hidup memerlukan begitu banyak barang. Setiap kegiatan memerlukan sarana dan prasarana yang berbeda. Selama ini pemerintah dan swasta sudah berupaya untuk memenuhi kebutuhan tersebu namun ada dua hal yang menjadi icatatan. Pertama ialah barang yang diberikan sering kali tidak tepat guna yang kedua terkait juga dengan masalah yang kedua yaitu pembinaan, tidak adanya pendampingan untuk penggunaan alat tersebut. Ketua RW 06 Meruya Utara mengatakan "kita diberikan mesin cacah sampah tetapi kita belum bisa menggunakan karena tidak adanya pendampingan”. Menyambung dengan permasalahan pembinaan juga demikian. Menurut ketua RW kegiatan kampung iklim dengan adanya elemen adaptasi dan mitigasi perubahan iklim ini banyak juga yang belum mengetahui dengan baik. Belum lagi ada juga masalah yang sangat kritis, banyak para penggiat yang sudah mulai tidak lagi percaya dengan program pemerintah. Fenomena ini menguat di dua kampung yaitu di Ciracas dan Duri Kosambi. Hal ini jika tidak segera diambil langkah-langkah yang strategis tentunya akan berdampak kontra produktif terhadap kelangsungan program, khususnya yang terkait dengan lingkungan hidup.

\section{FGD Kedua: Merumuskan Tata Kelola dan Arah Kampung Iklim}

Berdasarkan penjelasan sebelumnya diketahui bahwa selama ini dalam menjalankan program kampung iklim ada beberapa kendala yang mereka hadapi oleh para penggiat kampung iklim terutama terkait dengan upaya memperbaiki jejaring yang ada pada masingmasing kampung iklim. Oleh karenanya, pada FGD yang kedua, dilakukan diskusi yang intensif terkait dua hal; tata kelola organisasi kampung iklim dan program kerja kampung iklim.

\section{Tabel 4}

Rumusan Penggiat Kampung Iklim dan Prioritas Intervensi

\begin{tabular}{|c|c|c|c|}
\hline Lokasi & $\begin{array}{c}\text { Perubahan } \\
\text { Kelembagaan }\end{array}$ & $\begin{array}{c}\text { Program } \\
\text { Unggulan }\end{array}$ & Prioritas Intervensi \\
\hline Rorotan RW 01 & RW Terlibat Langsung & Ecopark & Pengurusan Legalitas \\
& & & Lahan \\
\hline Sunter Jaya RW & $\begin{array}{c}\text { Pembagian kerja pada } \\
\text { kelompok PKK dan } \\
09\end{array}$ & Produksi Bir & Budidaya Tanaman \\
& pengembangan Bank & & Herbal \\
& Sampah & & \\
\hline
\end{tabular}




\begin{tabular}{|c|c|c|c|}
\hline Rawasari RW 02 & $\begin{array}{c}\text { Pembagian kerja } \\
\text { berdasarkan kegiatan }\end{array}$ & Budidaya TOGA & $\begin{array}{c}\text { Dukungan budidaya } \\
\text { TOGA }\end{array}$ \\
\hline $\begin{array}{c}\text { Cempaka Putih } \\
\text { Timur RW 03 }\end{array}$ & $\begin{array}{c}\text { Dibentuknya } \\
\text { Penanggungjawab } \\
\text { Proklim }\end{array}$ & $\begin{array}{c}\text { Kampung Wisata } \\
\text { Hijau }\end{array}$ & $\begin{array}{c}\text { Dukungan budidaya } \\
\text { magot }\end{array}$ \\
\hline $\begin{array}{c}\text { Kebon Pala RW } \\
09\end{array}$ & $\begin{array}{c}\text { RW Terlibat Langsung } \\
\text { Ciracas RW 03 }\end{array}$ & $\begin{array}{c}\text { Penghijauan } \\
\text { Wilayah }\end{array}$ & Dukungan bibit pohon \\
\hline $\begin{array}{c}\text { Lenteng Agung } \\
\text { RW 09 }\end{array}$ & $\begin{array}{c}\text { Dibentuknya } \\
\text { Penanggungjawab } \\
\text { Proklim }\end{array}$ & $\begin{array}{c}\text { Produk Olahan } \\
\text { Perubahan Iklim }\end{array}$ & $\begin{array}{c}\text { Relasi dengan Sudin } \\
\text { LH dan KPKP }\end{array}$ \\
\hline Pengadegan RW \\
01
\end{tabular}

Sumber: diolah dari data Penelitian

Berdasarkan informasi dari tabel di atas diketahui bahwa ada perubahan pola kelembagaan yang terjadi setelah adanya intervensi melalui kegiatan FGD dan Rembug Kampung Iklim. Salah satu perubahan yang paling mendasar ialah pelibatan pengurus RW, khususnya di wilayah yang awalnya tidak terbangun antara penggerak dengan pengurus RW. Kampung iklim tersebut ialah Rorotan, Kebon Pala, dan Pangadegan. Selanjutnya, perubahan kelembagaan yang juga terjadi ialah kaitannya dengan pembagian kerja dari penggerak. Masing-masing program yang terkait dengan adaptasi dan mitigasi perubahan iklim dibentuk penanggungjawab program.

Kemudian, diketahui juga bahwa masing-masing kampung iklim memiliki prioritas yang berbeda-beda satu sama lain. Sebagian kampung iklim ingin mengembangkan kampung iklim mereka menjadi destinasi wisata yang menawarkan edukasi pada bidang adaptasi dan mitigasu perubahan iklim. Ada empat kampung yang memiliki orientasi tersebut, yaitu Rorotan, Pangadengan, Lenteng Agung, dan juga Meruya Utara. Kampung Iklim Rorotan 
diketahui memiliki harapan besar agar dapat menjadi destinasi wisata baru bertajuk ecopark. Hal ini dipahami karena mereka miliki lahan fasum yang sangat luas yang sudah dioptimalkan untuk kegiatan urban farming dan komposting. Namun, salah satu kendala terbesar ialah belum adanya serah terima lahan tersebut dari pengembang ke pihak warga ataupun pemerintah daerah kondisi ini sudah berlangsung selama lebih dari 20 tahun. Dengan ketidakjelasan status lahan tersebut tentunya menjadi penghambat dalam proses kerjasama dengan pemda maupun dunia usaha jika ingin membantu dalam pengadaan sarana dan prasarana.

Kampung Iklim Pangadengan ingin menjadi kampung wisata hidroponik. Mereka ingin menyinergiskan program hidroponik dengan produksi olahan pangan dari hasil budidaya sendiri. Mereka memiliki harapan bisa hidroponik akan menjadi daya tarik wisatawan datang dan mereka menyiapkan paket snack dan makan siang yang dibuat oleh masyarakat. Namun, sebelum perencanaan tersebut diimplementasikan, ada perihal yang menjadi prioritas untuk dilakukan yaitu penguatan soliditas penggerak kampung iklim. Hal ini penting mengingat masih adanya ketidakcocokan antar penggerak kampung iklim yang tentunya akan menjadi penghambat untuk pengembangan program dimasa yang akan datang.

\section{Foto 2}

FGD kedua di Taman Aries Meruya Utara RW 06

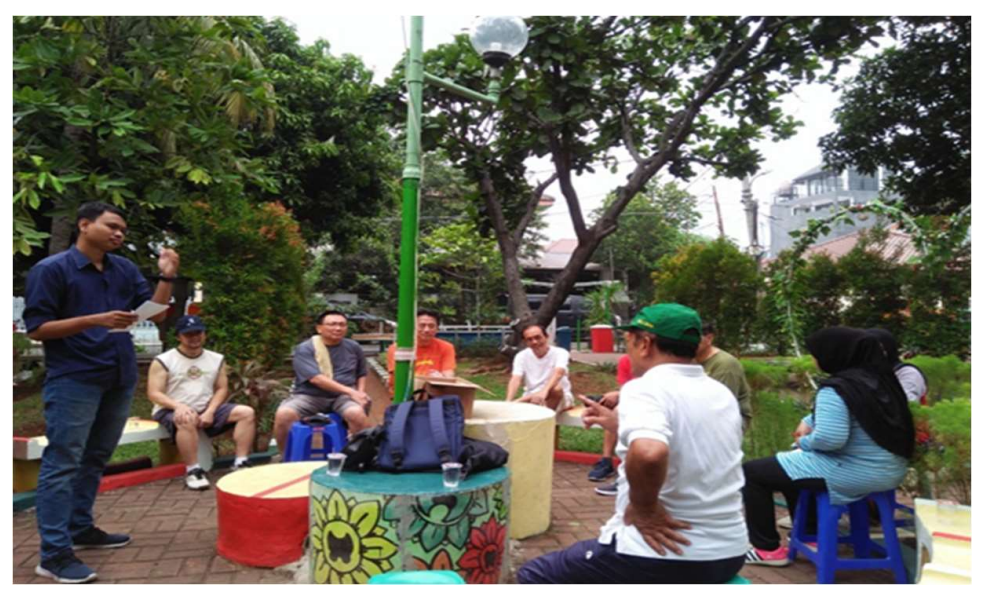

Sumber: Dokumentasi Tim Peneliti

Kampung Iklim Lenteng Agung merupakan lokasi yang sudah memiliki kelengkapan dari sisi adaptasi dan mitigasi perubahan iklim. Lengkapnya sarana dan prasarana pendukung ditambah dengan kondisi bentang alam kampung yang dikelilingi oleh Kali Ciliwung menjadi nilai tambah kampung iklim ini menjadi destinasi wisata. Apalagi selama ini sudah terbangun kerjasama yang baik dengan PLN dan MAT PECI dalam upaya rehabilitasi dan pemanfaatan 
kawasan pinggir kali. Namun yang perlu menjadi perhatian ialah lokasi kawasan pinggir kali yang dikembangkan merupakan bagian dari wilayah sungai sehingga pada saat musim hujan wilayah ini terendam air. Oleh karenanya, diperlukan kajian dan penelitian yang terpadu untuk memberikan rekomendasi teknis agar program disesuaikan dengan kondisi alam.

Kampung Iklim Meruya Utara memiliki komitmen agar taman Aries bisa dikembangkan menjadi taman edukasi adaptasi dan mitigasi perubahan iklim. Taman Aries selama ini sudah banyak dikunjungi oleh para pelajar dan masyarakat yang ingin tahu mengenai kegiatan lingkungan hidup yang dilaksanakan oleh pengurus RW. Kendala utama dalam pengembangan Taman Aries adalah masih terbatasnya warga yang terlibat dalam program. Dengan demikian, upaya intervensi yang prioritas ialah sosialisasi kegiatan kampung iklim bagi warga dan juga asisten rumah tangga di wilayah tersebut. Hal ini penting mengingat konteks pemukiman Meruya Utara RW 06 merupakan pemukiman elit yang interaksi antar warganya sangar rendah. Oleh karenanya, pelibatan asisten rumah tangga merupakan salah satu solusi agar kegiatan kampung iklim yang ada dapat dikelola secara rutin dan terpadu.

Kemudian ada tiga kampung iklim yang ingin mengembangkan kegiatan budidaya toga sekaligus upaya produksi olahan pangan dari bahan toga. Program ini sesungguhnya merupakan inisiasi dari TP PKK DKI Jakarta yang bertajuk taman hatinya PKK. Mereka diarahkan melakukan diversifikasi budidaya tanaman herbal pada masing-masing RT dalam satu RW. Kampung Iklim Rawasari dahulu pernah menjalankan program ini, namun saat ini program sudah meredup. Oleh karenanya, mereka berniat untuk mengembangkan kembali program tersebut. Di sisi lain, Kampung Iklim Sunter Jaya sudah dikenal sebagai produsen bir pletok dan wornas (wortel dan nanas) sayangnya selama ini bahan baku belum mereka hasilkan sendiri, semua bahan-bahan dibeli dari pasar. Hal ini mendorong mereka untuk melakukan budidaya tanaman herbal agar bahan produksi diperoleh dari taman mereka sendiri. Progres yang lebih baik dialami oleh kampung iklim Ciracas, mereka sudah memiliki taman herbal yang tersebar di setiap RT, kemudian mereka juga sudah mulai memproduksi olahan tanaman herbal menjadi berbagai produk seperti bubuk jahe merah dan bir peletok (wedang wuh) Selama kegiatan pendampingan, PKK kampung iklim Ciracas juga sedang dilatih oleh UHAMKA untuk melakukan produksi olahan makanan dari bahan-bahan yang ada di lingkungan mereka. 


\section{Foto 3}

Fit Tok Produk Olahan Herbal Kampung Iklim Ciracas

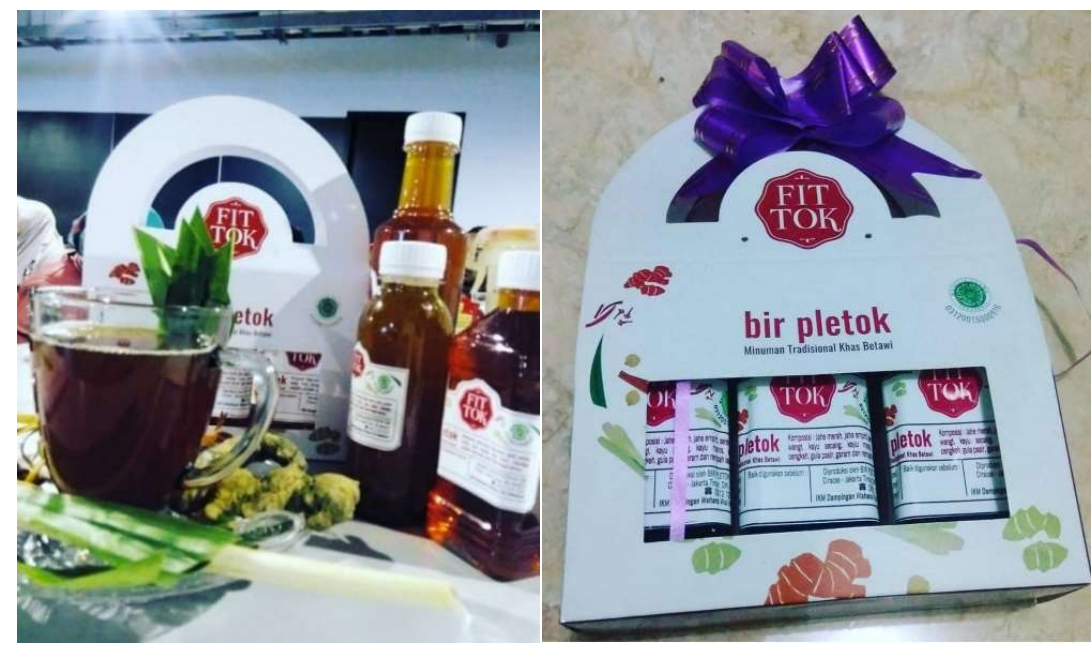

Sumber: dokumentasi PKK Kelurahan Ciracas

Dua kampung berikutnya fokus pada pengembangan program kampung iklim dibidang penghijauan dan pengolahan sampah anorganik dan organik. Kedua kampung ini memiliki kesamaan, yaitu bangkitnya semangat dan solidaritas bersama untuk membangun kampung iklim mereka. Pendampingan kampung iklim yang dilakukan oleh tim menjadi momentum kebangitan tersebut. Oleh karenanya, pendampingan lanjutan sangat penting dilakukan oleh suku dinas terkait untuk menjaga konsistensi semangat dan solidaritas tersebut. Kampung Kebon Pala membutuhkan dukungan bibit tanaman hias dan buah untuk mendukung program penghijauan mereka. Sedangkan untuk Duri Kosambi membutuhkan pengawalan agar lahan yang mereka akan bangun untuk lokasi bank sampah dan komposting bisa digunakan dalam tempo yang lama.

\section{Penutup}

Dengan penelitian kolaboratif yang telah dilakukan diketahui bahwa dengan menggunakan perspektif Plastrik dan Taylor (2004) mediasi melalui dua kali FGD dan rembug kampung iklim maka proses pembentukan jejaring sampai pada tingkat jejaring dinamis, yaitu di mana penggerak kampung iklim sudah dapat mengidentifkasi bagaimana mengembangkan jejaring, memonitoring dan mengevaluasi program, dan juga sudah bisa melakukan adaptasi program. Masalah utama dalam proses tersebut ialah ada beberapa pengurus RW yang selama ini tidak terlibat dalam program yang dilakukan oleh komunitas. Melalui proses partisipioatif ini, masalah tersebut mulai terurai dengan adanya kesepahaman melalui FGD-FGD yang 
dilakukan. Kondisi demikian tentunya menguatkan elemen jejaring yang ada pada sisi komunitas, baik pada sisi bounding, bridging, dan juga linking (lihat, Mahendro: 2013).

Kemudian terkait dengan konsep yang dikembangkan oleh Plastrik dan Taylor (2006), diketahui bahwa pendampingan dan mediasi kegiatan yang dilakukan juga sudah memberikan tingkatan jejaring pada tingkat produktif bagi beberapa wilayah kampung iklim. Hal ini diapahami dengan naiknya posisi tawar dari kampung iklim, karena melalui proses pendampingan yang dilakukan mereka kini bukan lagi merasa sebagai 'objek' tetapi menjadi 'subjek' dalam ranah perbaikan lingkungan hidup di wilayah mereka sendiri bahkan lebih luas DKI Jakarta. Dengan penyusunan program kerja mereka dapat menentukan pola dan bentuk intervensi dari jejaring eksternal yang mereka butuhkan dengan merujuk pada kesepakatan bersama yaitu struktur organisasi dan juga program kerja kampung iklim.

\section{Daftar Pustaka}

Engestrom, Yrjo. 1999. Activity Theory and Individual and Social Transformation. Cambridge University Press.

Faedlulloh, Dodi, Bambang Irawan dan Retnayu Prasetyanti. 2019. Program Unggulan Kampung Iklim (Proklim) Berbasis Pemberdayaan Masyarakat. PUBLISIA: Jurnal Ilmu Administrasi Publik. Volume: 4 (1) 2019.

Ghina, Nabiila Yumna dan Siti Zunariyah. 2017. Kampung Iklim: Pengelolaan Lingkungan Berbasis Pemberdayaan Masyarakat. Jurnal Sosiologi DILEMA, Vol. 32, No. 2 Tahun 2017. Jurusan Sosiologi FISIP UNS.

Koshy, Valsha. 2005. Action Research for Improving Practice A Practical Guide. Sage Publication Inc. Plastrik, Peter and Taylor, Madeiline. 2004. Network Power for Philanthropy and Nonprofits. Massachusetts: Barr Foundation.

Plastrik, Peter and Taylor, Madeiline. 2006. Net Gains: A Handbook for Network Builders Seeking Social Change. Wendling Foundation.

Mahendro, Anggoro Yudo. 2018. Relasi Institusi Formal dan Informal dalam Pengelolaan Sampah: Studi Pada Perkumpulan Sosial di RW 07 Pabuaran Tumpeng Kota Tangerang. Indonesian Journal of Sociology and Education Policy Vol. 3, No. 1, Januari 2018. Jurusan Sosiologi FIS UNJ.

Mahendro, Anggoro Yudo. 2018. Strategi Penguatan Pelibatan Masyarakat dalam Program Kampung Iklim: Studi Pada Bebeberapa Wilayah di DKI Jakarta. Indonesian Journal 
of Sociology and Education Policy Vol. 3, No. 2, Juli 2018. Jurusan Sosiologi FIS UNJ.

Mahendro, Anggoro Yudo. 2013. Menggantung Ke Atas: Perkumpulan Sosial Pedesaan di Era Desentralisasi. Jurnal Sosiologi Masyarakat Departemen Sosiologi FISIP UI, Vol 18, No. 2 Juli 2013.

Rifyanti, Rike. 2018. Evaluasi Program Kampung Iklim Dalam Mengurangi Risiko Dampak Perubahan Iklim Desa Ngelegi, Kecamatan Patuk, Kabupaten Gunung Kidul. Skripsi. Program Studi Perencanaan Wilayah dan Kota. Fakultas Teknik. Universitas Gajah Mada.

Wahab, Ali Akbar. 2015. Strategi Pengembangan Pprogram Kampung Iklim (Proklim) Di Desa Mangepang, Kecamatan Bungaya, Kabupaten Gowa Provinsi Sulawesi Selatan. Thesis. Program Studi Pengelolaan Lingkungan. Program Pasca Sarjana. Universitas Hasanuddin. 